\title{
Role of the uterus in oestradiol-induced luteal regression in the ewe
}

\author{
P. K. Chakraborty* and F. Stormshak \\ Department of Animal Science, Oregon State University, Corvallis, Oregon 97331, U.S.A.
}

A single injection or two consecutive daily injections of oestradiol into intact ewes from Days 9 to 13 of the oestrous cycle induce premature luteal regression (Stormshak, Kelley \& Hawk, 1969; Hawk \& Bolt, 1970; Howland, Akbar \& Stormshak, 1971). If the ewes are hysterectomized on Days 5 or 9 of the cycle, oestradiol administered between Days 9 and 13 does not cause regression of the CL, suggesting an involvement of the uterus in the effect of oestradiol on the CL (Stormshak et al., 1969; Bolt \& Hawk, 1975). It has been proposed that the uterine luteolysin in the ewe is prostaglandin F-2 $\alpha$ (McCracken et al., 1972), and oestradiol injection on Days 9 and 10 of the cycle results in an increased concentration of prostaglandin F-2 $\alpha$ in uterine venous plasma $18 \mathrm{hr}$ after the last injection (Ford et al., 1975).

The present experiment was conducted to investigate the effect of hysterectomy on luteal weight and progesterone content at various times following oestradiol treatment of ewes.

Fifteen mature crossbred ewes were observed for oestrus twice daily using vasectomized rams and were allowed to complete at least one oestrous cycle of normal duration before being assigned at random in equal numbers to three treatment groups. Ewes in all three groups were given an i.m. injection of $750 \mu \mathrm{g}$ oestradiol-17 $\beta$ dissolved in corn oil on each of Days 10 and 11 of the cycle (first day of oestrus $=$ Day 0 of the cycle) and hysterectomized as follows: Group 1, immediately before the first injection ( $0 \mathrm{hr})$; Group 2, $24 \mathrm{hr}$ after the first injection and immediately before the second injection; and Group 3, $48 \mathrm{hr}$ after the first injection. The ovaries and uterus of each ewe were exposed through a midventral incision at the designated times; the number of $\mathrm{CL}$ in each ovary was recorded and the uterus, including the uterotubal junctions and the proximal half of the cervix, were excised. Care was taken to ensure that the ovarian arteries and veins were not severed or occluded. All ewes were killed on Day 15 of the cycle and the CL were enucleated and weighed. Luteal tissue was stored in $95 \%$ ethanol until analysed for progesterone content by the procedure described by Stormshak, Leverage, Kelley, Gerrits \& Howland (1970), except that one-half of each sample was spotted on a thin-layer chromatogram and developed in one dimension for $2 \mathrm{hr}$ in a solvent system of chloroform: methanol $(99: 1 \mathrm{v} / \mathrm{v})$. Sample steroids were eluted from the silica gel with $10 \mathrm{ml}$ chloroform: methanol $(2: 1 \mathrm{v} / \mathrm{v})$. Mean recovery of $\left[4-{ }^{14} \mathrm{C}\right]$ progesterone added to the luteal samples before analysis was $92 \cdot 1 \pm 3 \cdot 7 \%$.

Luteal characteristics were analysed statistically by use of analysis of covariance using number of $\mathrm{CL}$ as the independent variable. Differences between group treatment means were tested for significance by use of Duncan's multiple range test.

The effect of time of hysterectomy on mean luteal characteristics of oestradiol-treated ewes is shown in Table 1. Luteal weights varied significantly. Luteal progesterone content was not significantly affected but there were some differences in progesterone concentrations.

The results of the present experiment indicate that the uterus needs to be present for more than 24 $\mathrm{hr}$ after injection of oestradiol for the hormone to bring about premature luteal regression during mid-cycle in the ewe. The CL failed to regress when the uterus was removed before $(0 \mathrm{hr})$ or $24 \mathrm{hr}$ after the initial oestradiol injection. If prostaglandin F-2 $\alpha$ is the natural luteolysin in the ewe, then stimulation of uterine synthesis and/or release of prostaglandin during the first $24 \mathrm{hr}$ after treatment with oestradiol in the present study appeared to be insufficient to cause luteal regression.

*Present address: Department of Surgery, University of Oregon, Health Sciences Center, Portland, Oregon 97201 , U.S.A. 
Table 1. Effect of time of hysterectomy on mean ( \pm S.E.M.) luteal characteristics (adjusted for no. of $C L$ by use of covariance) of ewes injected with $750 \mu \mathrm{g}$ oestradiol-17 $\beta$ on Days 10 and 11 of the oestrous cycle

\begin{tabular}{ccccc}
\hline Group & $\begin{array}{c}\text { Time of } \\
\text { hysterectomy* }\end{array}$ & $\begin{array}{c}\text { Luteal } \\
\text { weight }(\mathrm{mg})\end{array}$ & $\begin{array}{c}\text { Progesterone } \\
\text { content }(\mu \mathrm{g})\end{array}$ & $\begin{array}{c}\text { Progesterone } \\
\text { conc. }(\mu \mathrm{g} / \mathrm{g})\end{array}$ \\
\cline { 4 - 6 } 1 & $0 \mathrm{hr}$ & $508 \cdot 3 \pm 20 \cdot 6^{a}$ & $20 \cdot 9 \pm 4 \cdot 2^{a}$ & $34 \cdot 0 \pm 3 \cdot 9^{a, b}$ \\
2 & $24 \mathrm{hr}$ & $480 \cdot 1 \pm 21 \cdot 5^{a}$ & $15 \cdot 6 \pm 4 \cdot 4^{a}$ & $24 \cdot 2 \pm 4 \cdot 0^{b}$ \\
3 & $48 \mathrm{hr}$ & $400 \cdot 6 \pm 21 \cdot 0^{b}$ & $23 \cdot 2 \pm 4 \cdot 3^{a}$ & $41 \cdot 2 \pm 4 \cdot 0^{a}$ \\
\hline
\end{tabular}

$a, b$ Means of each luteal characteristic not having an identical superscript are significantly different $(P<0.05)$.

* Relative to first oestradiol injection.

Technical Paper No. 3237, Oregon Agricultural Experiment Station.

\section{References}

BolT, D.J. \& HaWk, H.W. (1975) Prevention of estrogeninduced regression of corpora lutea in ewes by hysterectomy. J. Anim. Sci. 40, 687-690.

Ford, S.P., Weems, C.W., Pitts, R.E., Pexton, J.E., BUTCHER, R.L. \& INSKEEP, E.K. (1975) Effects of estradiol-17 $\beta$ and progesterone on prostaglandins $F$ in sheep uteri and uterine venous plasma. J. Anim. Sci. 41, 1407-1413.

HAWK, H.W. \& BoLt, D.J. (1970) Luteolytic effect of estradiol-17 $\beta$ when administered after midcycie in the ewe. Biol. Reprod. 2, 275-278.

Howland, B.E., Akbar, A.M. \& Stormshak, F. (1971) Serum LH levels and luteal weight in ewes following a single injection of estradiol. Biol. Reprod. 5, 25-29. McCracken, J.A., Carlson, J.C., Glew, M.E., Goding, J.R., BaIrd, D.T., GReEN, K. \& SAMUELsson, B. (1972) Prostaglandin $F_{2 \alpha}$ identified as a luteolytic hormone in sheep. Nature, New Biol. 238, 129-134.

StormshaK, F., Kelley, H.E. \& Hawk, H.W. (1969) Suppression of ovine luteal function by $17 \beta$-estradiol. J. Anim. Sci. 29, 476-478.

Stormshak, F., Leverage, W.E., JR, Kelley, H.E., GerRITS, R.J. \& Howland, B.E. (1970) Hypothalamo-hypophysial and ovarian characteristics of gilts fed methallibure. J. Anim. Sci. 30, 556-560.

Received 24 May 1976 